\title{
Aloe vera gel as a Novel Edible Coating for Fresh Fruits: A Review
}

\author{
Jawadul Misir", Fatema H. Brishti, M. M. Hoque \\ Department of Food Engineering and Tea Technology, Shahjalal University of Science and Technology. Sylhet, Bangladesh \\ *Corresponding author: jawad_misir28@yahoo.com
}

Received May 04, 2014; Revised June 09, 2014; Accepted June 18, 2014

\begin{abstract}
New technological advances in antimicrobial edible coatings for food may hold promise in extending shelf life, reducing packaging layers, meeting food safety and quality requirements. Emerging research shows polysaccharides, bacteriocins, essential oils, enzymes, proteins and lipids are all natural coatings that have unrealized potential in food preservation. Recently, interest has increased in using Aloe vera gel-based edible coating material for fruits and vegetables. Aloe vera gel has been proven one of the best edible and biologically safe preservative coatings for different types of foods because of its film-forming properties, antimicrobial actions, biodegradability and biochemical properties. It is composed mainly of polysaccharides and acts as a natural barrier to moisture and oxygen, which are the main agents of deterioration of fruits and vegetables. Aloe vera gel has the ability to prolong shelf life of the fruits and vegetables by minimizing the rate of respiration and maintaining quality attributes (color, flavor etc.). It has antifungal and antibacterial property which provides a defensive barrier against microbial contamination of fruits and vegetables. The present review describes the preparation, properties and potential application of Aloe vera gel coatings for enhancing the postharvest life and quality of different types of fruits.
\end{abstract}

Keywords: Aloe vera gel, edible coating, fruits, postharvest life, shelf life

Cite This Article: Jawadul Misir, Fatema H. Brishti, and M. M. Hoque, "Aloe vera gel as a Novel Edible Coating for Fresh Fruits: A Review.” American Journal of Food Science and Technology, vol. 2, no. 3 (2014): 93-97. doi: 10.12691/ajfst-2-3-3.

\section{Introduction}

Consumers around the world demand for food of highquality, without chemical preservatives, and an extended shelf life. Therefore, an increased effort has been made to develop new natural preservatives and antimicrobials [19]. Many storage techniques have been developed to extend the marketing distances and holding periods for commodities after harvest. Different preservation methodologies have been developed. One method of extending post harvest shelf life is the use of the edible coatings [6]. Edible films and coatings have received considerable attention in recent years because of their advantages including use as edible packaging materials over synthetic films.

Edible coatings are thin layers of edible material applied to the product surface in addition to or as a replacement for natural protective waxy coatings and provide a barrier to moisture, oxygen and solute movement for the food $[4,24]$. They are applied directly on the food surface by dipping, spraying or brushing [24]. Edible coatings are used to create a modified atmosphere and to reduce weight loss during transport and storage [6]. In fact, the barrier characteristics of gas exchange for films and coatings are the subjects of much recent interest [36].

Aloe vera is a well-known plant for its marvelous medicinal properties. It is a tropical and subtropical plant. Recently, researchers from Spain have developed a gel based on Aloe vera that prolongs the conservation of fresh fruits [37]. This gel is tasteless, colorless and odorless. This natural product is a safe and environmentally friendly alternative to synthetic preservatives such as sulfur dioxide. According to the researchers, this gel operates through a combination of mechanics [33], forming a protective layer against the oxygen and moisture of the air and inhibiting the action of micro-organisms that cause food borne illnesses through its various antibacterial and antifungal compounds. Aloe vera gel-based edible coatings have been shown to prevent loss of moisture and firmness, control respiratory rate and maturation development, delay oxidative browning and reduce microorganism proliferation in fruits such as table grapes [11], sweet cherries [22] and nectarines [2]. The main goal of this article is to critique and update the information available on Aloe vera gel properties, its preparation and on the use of Aloe vera gel coatings as an effective preservative to improve the safety, quality and functionality of fresh fruits.

\section{Aloe Vera}

The word Aloe derived from the word Arabic "Alloeh" or the Hebrew "Halal" meaning "bitter, shinny substance" [15]. Aloe vera is known as "plant of immortality" by the Egyptians due to its beneficial effect on human health. It is generally presumed that the origin is Arabia, Somalia, 
Sudan, and Oman. At present, Aloe vera is widely distributed throughout the tropics and subtropics [32]. Aloe vera is a perennial plant. It's thick, thorn- edged leaves, ranging in color from gray to bright green, give aloe vera the appearance of a cactus, but, it is, in fact, a member of the lily family (Liliaceae). A typical Aloe vera plant produces two or three yellow tubular flowers, shaped much like those of the Easter Lily, and it flowers intermittently throughout the year [15]. It's thick leaves contain the water supply of the plant to survive long periods of drought. The leaves have a high capacity of retaining water also in very warm dry climates and therefore this plant can survive very harsh circumstances where most other vegetation disappears.

There are two distinct layers of Aloe vera leaves which are clearly visible in transverse section: the green outer leaf rind and the soft, colorless, inner gel parenchyma. Aloe vera is an unique plant which is a rich source of many chemical compounds. Prof. Tom D. Rowe [31] was probably first to take vital steps in the chemical analysis of the plant. Aloe vera now reported to contain as many as 75 nutrients and 200 active compounds including sugar, anthraquinones, saponins, vitamins, enzymes, minerals, lignin, salicylic acid and amino acids [13]. In today's society many people have food allergies or personal preferences that would prevent them from ingesting these items. Therefore, Aloe vera is a great dietary source to meet those amino acids needs.

\section{Constituents of Aloe Vera Gel}

The components of Aloe vera can be divided into the following class [33]:

\begin{tabular}{|c|c|}
\hline Class & Compounds \\
\hline Anthraquinones & $\begin{array}{c}\text { Aloin/Barb-aloin, Isobarba-aloin, Aloe-emodin, } \\
\text { Emodin, Aloetic acid, Ester of cinnamic acid, } \\
\text { Anthranol, Chrysophanic acid, Resistannol } \\
\text { Anthracene, Ethereal oil. }\end{array}$ \\
\hline Vitamins & $\begin{array}{c}\text { B1, B2,B6, A-Tocopherol, } \beta \text {-Carotene, Choline, } \\
\text { Folic acid, Ascorbic acid }\end{array}$ \\
\hline Enzymes & $\begin{array}{c}\text { Cyclo-oxygenase, Oxidase, Amylase, Catalase, } \\
\text { Lipase, Alkaline- phospahatase, Carboxy-peptidase }\end{array}$ \\
\hline Miscellaneous & $\begin{array}{c}\text { Cholesterol, Steroids, Tricylglycerides, } \beta \text { - } \\
\text { Sitosterol, Lignins, Uric Acid, Gibberellin, Lectin } \\
\text { like substances, Salicylic Acid, Arachidonic Acid }\end{array}$ \\
\hline Saccharides & Mannose, Glucose, L-Rhamnose, Aldo-pentose \\
\hline Carbohydrates & $\begin{array}{c}\text { Cellulose, acetylated mannan, Arabinogalactan, } \\
\text { Xylan, Pure mannan, pectic substance, } \\
\text { glucomannan, Glucogalc-tomannan, Galactan }\end{array}$ \\
\hline Inorganic & Calcium, Sodium, Chlorine, Manganese, Zinc, \\
Compunds & Chromium, Copper, Magnesium, Iron \\
\hline $\begin{array}{c}\text { Non-essential } \\
\text { Amino acids }\end{array}$ & $\begin{array}{c}\text { Histidine, Arginine, Hydroxyproline, Aspartic } \\
\text { Acid, Glutamic Acid, Proline, Glycine, Alanine }\end{array}$ \\
\hline Essential Amino \\
acids & $\begin{array}{c}\text { Lysine, Threonine, Valine, Leucine, Iso-leucine, } \\
\text { Phenyl-alanine, Methionine }\end{array}$ \\
\hline
\end{tabular}

\section{Preparation of Aloe Vera Gel Matrix}

Fresh Aloe vera leaves were harvested. Aloe gel matrix lies underneath the green outer leaf rind. The gel matrix was separated from the outer cortex of leaves and this colorless hydroparenchyma was ground in a blender. The resulting mixture was then filtered to remove the fibers. The liquid obtained was the fresh Aloe gel (AG; 100\%). The Aloe gel was pasteurized at $70^{\circ} \mathrm{C}$ for $45 \mathrm{~min}$ [23]. It was then cooled immediately at ambient temperature. To facilitate coating the gel was thickened using $1 \%$ gelling agent. This gel finally applied to coat fresh fruits or vegetables by means of brushing, spraying or dipping.

\section{Antimicrobial Activity of Aloe Vera Gel}

An antimicrobial is a substance that kills or inhibits the growth of microbes such as bacteria (antibacterial activity), fungi (antifungal activity), viruses (antiviral activity), or parasites (anti-parasitic activity). Reference [16] found that $A$. vera gel has inhibited the growth of both gram positive and gram negative bacteria. Aloe gel composed of a wide range of constituents which are mainly responsible for this antimicrobial activity against various microorganisms. Anthraquinones presented antimicrobial activity against Staphylococcus aureus strains and against Escherichia coli, through inhibition of solute transport in membranes $[17,20]$. Emodine has been reported to be effective against several gram positive bacteria (Cock, 2008). There are some reports on the antifungal activity of Aloe vera gel against several fungi including Colletotrichum sp. [27]. According to reference [34], Aloe vera gel showed good antibacterial activity against some food borne pathogenic microorganisms such as Bacillus cereus, Salmonella typhimurium, Escherichia coli, Klebsialla pneumonia etc.

\section{Aloe Vera Gel : A Promising Alternative to Synthetic Preservative}

Sales of seasonal fruits ripened and made fresh with harmful chemicals possess a serious threat to public health. A section of unscrupulous traders is selling the food items cheating a large number of innocent consumers. They use carbide in fruits like bananas, pineapples, oranges, grapes, apricots, papayas etc. to keep them fresh. They also use textile dye in papaya, pomegranate and other fruits. Harmful plant growth hormones and chemicals are also indiscriminately used in fruit orchards. To ripen faster, papaya fruits are dipped into calcium carbide and ethephone. These chemicals are highly toxic and pose great risk to consumer's health.

Although a number of edible coatings have been developed to preserve food freshness, the new coating is believed to be the first to use Aloe vera, according to study leader Daniel Valero of the University of Miguel Hernandez in Alicante, Spain. Valero and his associates found that Aloe vera gel is edible, invisible, odorless and does not affect the taste of fruits and vegetables on which it is applied. It also poses no risk to human health. It holds the potentiality to preserve fruits effectively due to its anti-microbial action, which is described in the beginning.

\section{Effect of Aloe Vera Gel Coating on Physico-chemical Properties of Fruit}

\subsection{Weight Loss}

Weight loss mainly occurs due to water loss by transpiration and loss of carbon reserves due to respiration [39]. The rate at which water is lost depends on the water pressure gradient between the fruit tissue and the 
surrounding atmosphere. Aloe gel based edible coating act as barrier, thereby restricting water transfer and protecting fruit skin from mechanical injuries.

Aloe vera gel (100\%) has been used to preserve papaya fruit at room temperature $25^{\circ} \mathrm{C}-29^{\circ} \mathrm{C}$ and $82-84 \% \mathrm{RH}$. All samples demonstrated a gradual loss of weight during storage. Throughout storage, the weight loss of uncoated fruit (sample) was significantly greater than that of Aloe gel coated fruit. At the end of the storage, uncoated papaya showed $22.5 \%$ loss in weight, whereas the weight losses of samples coated with Aloe vera gel was 7.93\% [8]. An experiment has also been carried out to maintain quality and safety of table grapes by coating with Aloe vera gel in cold storage $\left(1^{\circ} \mathrm{C}, 95 \%\right)$. Weight loss increased during cold storage and it was significantly greater in control (uncoated fruits) than in Aloe-coated grapes. At the end of cold storage, control fruits lost $15.51 \pm 0.32 \%$, whereas the loss of weight in Aloe-treated grapes was 8.13 $\pm 0.59 \%$ [37].

Apart from these, Aloe vera gel coating has also been effective in controlling water loss from other commodities, including pine-apple [91], sweet cherry [22], Granny Smith and Red Chief apples [14]. This positive effect in terms of reduction of moisture loss may be due to the hygroscopic properties of Aloe gel that allow the formation of water barrier between the fruit and the surrounding environment. Thus, preventing its external transferences [25]. Interestingly, Aloe vera gel mostly composed of polysaccharide [26] which is highly effective as a barrier against moisture loss without incorporation of lipid.

\subsection{Total Soluble Solid, Titrable Acidity and Ascorbic Acid}

Fruits are essential for the proper maintenance of human health. Fruits are foods rich in vitamins, minerals and supply arrays of colors, flavor, texture and bulkiness to the pleasure of eating. Reference [37] reported that $A$. vera led to a lower increase in TSS (Total Soluble Solid) and greater TA content (Titrable Acidity) retention of coated berries, which indicated that control (uncoated fruits) fruits presented a more pronounced maturation development than coated berries during storage periods $\left(1^{\circ} \mathrm{C}, 95 \% \mathrm{RH}+4\right.$ days at $\left.20^{\circ} \mathrm{C}, 90 \% \mathrm{RH}\right)$.

In case of Aloe coated and uncoated oranges $\left(12{ }^{\circ} \mathrm{C}\right.$, 96$98 \% \mathrm{RH})$, there were no significant differences in TSS and TA content of fruits during storage periods. The value of ascorbic acid content for coated oranges was found to be higher than that of uncoated fruits [3]. Reference [8] found that ascorbic acid content was higher in Aloe coated papaya fruits $(86.55 \mathrm{mg})$ than the control fruits $(61.10 \mathrm{mg})$ during the storage period at temperatures $25^{\circ} \mathrm{C}-29^{\circ} \mathrm{C}$ and 82-84\% RH.

A similar result was found in Aloe gel coated nectarines [2]. This was due to low oxygen permeability of coating which delayed the deteriorative oxidation reaction of ascorbic acid content [5]. Also reference [35] reported that coating reduces respiration of the fruits and retains the ascorbic acid in the fruits.

\subsection{Decay Percentage}

Decay percentage was used to observe the effectiveness of coated material on fruit in retarding fruit disease. A. vera gel was successful in reducing microorganism proliferation in table grape, the effect being higher for yeast and molds than for mesophillic aerobics [37]. Interestingly, the Aloe vera gel coating was effective in controlling microbial growth of 'Starking' cherry and 'Crimson' table grape without incorporation of other antimicrobial compounds such as garlic oil, potassium sorbate and nisin to increase the activity [29,30].

In case of Aloe vera coated papaya fruits, no disease signs were observed until 1 week after the beginning of the storage period. At the end of the storage period, 100\% disease incidence was observed in uncoated fruits, whereas for Aloe gel coated fruits disease incidence was only $27 \%$ [8]. This was due to the anti-microbial potentiality of coated materials which has been discussed earlier.

\subsection{Color}

Visual assessment is the first impression and a key feature in the choice of fruits. Color is one of the most important visual attributes of fruits. According to reference [14], Aloe vera gel treatment delayed the green color loss on the fruit skin of apples stored at $2^{\circ} \mathrm{C}$ for 6 months. Skin color of table grapes showed lower increases in Aloe treated than in control (untreated) fruits. Table grapes are rich in anthocyanin compounds, which account for their red color. The ripening process of table grapes has been correlated to the anthocyanin content [9]. At the end of cold storage $\left(1^{\circ} \mathrm{C}, 95 \% \mathrm{RH}\right)$, control fruits exhibited a redder and darker color than Aloe-treated ones, showing the aspect of overripe fruit, which is considered to be detrimental to color quality [37].

The modified atmosphere created by the Aloe vera gel coating material retarded the ethylene production rate, therefore, delaying ripening, chlorophyll degradation, anthocyanin accumulation and carotenoid synthesis thus ultimately delaying color change of fruits [10].

Color also retain in Aloe gel (100\%) treated papaya fruit [8]. Moreover, the A. vera coating imparted an attractive natural-looking sheen to table grapes [37], papaya [8] which was correlated to lower changes in both skin color and dehydration.

\subsection{Firmness}

Texture is a critical quality attribute in the consumer acceptability of fresh fruit and vegetables. The rate and extension of firmness loss during storage are the main factors determining fruit quality and postharvest shelf life. Fruits softening considerably occur as a result of degradation of the middle lamella of cell wall. Changes in cell wall structure and in their composition is mainly due to joint action of enzymes hydrolases, particularly polygalacturonase $(\mathrm{PG}), \quad$ pectinestarage $(\mathrm{PE}), \beta$ Galactosidase $(\beta-\mathrm{Gal})$, pectate lyase $(\mathrm{PL})$ and cellulose (Cel).

Aloe treatment significantly reduced the firmness losses of table grapes during cold storage $\left(1^{\circ} \mathrm{C}, 95 \% \mathrm{RH}\right)$ whereas losses of $>50 \%$ were detected in control grapes after 21 days of cold storage plus 4 days at $20^{\circ} \mathrm{C}$.

Papaya treated with $100 \%$ Aloe gel and control fruits presented similar initial flesh firmness values during the storage period of eight days at $25^{\circ} \mathrm{C}-29^{\circ} \mathrm{C}$ and $82-84 \% \mathrm{RH}$. At the end of the storage, control fruits decayed and the 
coated fruits were slightly soft but did not differ significantly [8]. This indicated that the ripening of coated fruits was delayed by delaying softening. Aloe vera gel has been proved to maintain the texture of fruit efficiently. This may be due to the effect of $A$. vera gel on the reduction of $\hat{a}$-galactosidase, polygalacturonase, and pectinmethyl-esterase activities [28].

\subsection{Respiration Rate}

It is known that the environmental temperature affects the fruit respiration and the respiration affects the fruit temperature in return [21]. When the temperature around the fruit rises, the respiration increases which leads to the increase of the temperature inside the fruit. The lower the respiration rate during storage the higher the shelf life of fruits and vice versa. The Aloe vera gel coating has significantly reduced the breathing rate. According to reference [2], 'Arctic Snow' nectarines was treated with Aloe gel and stored at $20 \pm 1^{\circ} \mathrm{C}$ to evaluate the ripening and quality attributes. Initially, Aloe vera gel coated and uncoated fruit did not exhibit any significant change in respiration rate. Later on, the control fruit's respiration rate increased more rapidly and exhibited a $41 \%$ higher respiration rate compared to the Aloe vera gel coated fruit.

In case of Aloe coated table grapes $\left(1^{\circ} \mathrm{C}, 95 \% \mathrm{RH}+4\right.$ days at $20^{\circ} \mathrm{C}, 90 \% \mathrm{RH}$ ), a controlled respiration rate has been observed than the uncoated fruits [37]. Application of a surface coating has been reported to increase resistance of fruit skin to gas diffusion and the creation of a modified internal atmosphere [7]. The reduced respiration in Aloe vera gel coated fruit may be ascribed to the hygroscopic properties that enable the formation of a barrier to diffusion of gasses and water vapour between fruit and environment [25]. Similarly, reduced respiration rate has been observed in Aloe vera gel coated sweet cherry [22].

\subsection{Overall Appearance of Aloe vera Coated Fruits}

The overall appearance of Aloe vera coated papaya fruits $\left(25^{\circ} \mathrm{C}-29^{\circ} \mathrm{C}\right.$ and $\left.82-84 \% \mathrm{RH}\right)$ were well described by reference [8]. Aloe vera coated papaya fruits has greater retention of bright green color than the uncoated fruits, which means ripening has delayed in coated fruits. Aloe coated papaya fruits were slightly soft at the end of the storage whereas control fruits already damaged. During storage period the judging panel found that flavor was satisfactory in Aloe vera coated papaya fruits.

Reference [37] found that Aloe vera coated table grapes $\left(1^{\circ} \mathrm{C}, 95 \% \mathrm{RH}+4\right.$ days at $\left.20^{\circ} \mathrm{C}, 90 \% \mathrm{RH}\right)$ looked shiny and attractive. The coated fruits did not produce any bad odor or off-flavor.

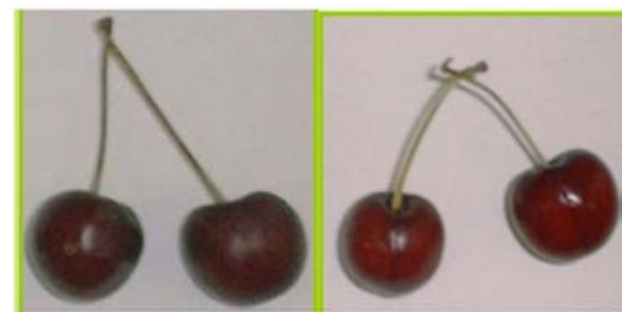

Figure 1. Visual aspect of Control and Aloe gel coated Cherry Fruits stored at 16 days $1^{\circ} \mathrm{C}+2$ days at $20^{\circ} \mathrm{C}$ respectively
According to the judging panel, cherry fruit coated with Aloe vera gel $\left(16\right.$ days $1^{\circ} \mathrm{C}+2$ days at $20^{\circ} \mathrm{C}$ ) had a better appearance than the control fruits. Control cherry fruits showed severe symptoms of dehydration and browning during storage periods. None of the judges detected the appearance of off-flavors or aromas in cherries coated with Aloe vera gel [22] (Figure 1).

\section{Conclusion}

Post harvest losses of fruits and vegetables are a matter of concern for all those nations whose economy is based on agriculture. Fruits face tremendous loss due to oldfashioned preservation practice and ignorance about the preservation strategies. To effectively extend the shelf life of postharvest fruits and vegetables, Aloe vera gel-based coating as a relatively convenient and safe measure, is more and more concerned in food industry in recent years. Another advantage of this coating is totally harmless to the environment. In fact it can be considered as a green alternative to synthetic coatings and other postharvest chemical treatments. The Aloe vera gel coating has wide application value in fresh fruit, vegetable or their fresh-cut materials. Since the storage condition of fruit and vegetable is improved, more nutrients are also reserved. The Aloe vera gel coating would have a wide prospect in the preservation of post-harvest fruits and vegetables in the future.

\section{References}

[1] Adetunji, C.O., Fawole, O.B., Arowora, K.A., Nwaubani, S.I., Ajayi, E.S., Oloke, J. K., Majolagbe, O.M., Ogundele, B. A., Aina, J.A., Adetunji, J.B., “ Effects of Edible Coatings from Aloe Vera Gel on Quality and Postharvest Physiology of Ananas Comosus (L.) Fruit During Ambient Storage”, Global Journal of Science Frontier Research, 12 (5). 39-43. 2012.

[2] Ahmed, M. J., Singh, Z., \& Khan, A.S., "Postharvest Aloe vera gel-coating modulates fruit ripening and quality of 'Arctic Snow' nectarine kept in ambient and cold storage”, International Journal of Food Science and Technology, 44 (5). 1024-1033. 2009.

[3] Arowora, K.A., Williams, J.O., Adetunji, C.O., Fawole, O.B., Afolayan, S.S., Olaleye, O.O., Adetunji, J.B. and Ogundele, B.A.,"Effects of Aloe vera coatings on quality characteristics of oranges stored under cold storage", Greener Journal of Agricultural Sciences, 3 (1). 039-047.2013.

[4] Avena-Bustillos, R.J., Krochta, J.M., and Saltveit, M.E., "Water vapor resistance of red delicious apples and celery sticks coated with edible caseinate-acetylated monoglyceride films", Journal of Food Science, 62 (2). 351-354.1997.

[5] Ayranci, E. \& Tunc, S., "A method for the measurement of the oxygen permeability and the development of edible films to reduce the rate of oxidative reactions in fresh foods", Journal of Food Chemistry, 80 (3). 423-431. 2003.

[6] Baldwin, E.A., Nisperos, M.O., and Baker, R. A., "Edible coatings for lightly processed fruits and vegetables”, HortScience. 30-35. 1995.

[7] Banks, N.H., Dadzie, B.K. \& Cleland, D.J., "Reducing gas exchange of fruits with surface coating”, Postharvest Biology and Technology, 3 (3). 269-284. 1993.

[8] Brishti, F.H., Misir, J. and Sarker A., "Effect of Biopreservatives on storage life of Papaya fruit (Carica Papaya L.)”, Intermational Journal of Food Studies, 2 (1). 126-136. 2013.

[9] Cantos, E., Espi'n, J.C., Toma's-Barbera'n, F.A., "Varietal differences among the polyphenol profiles of seven table grape cultivars studied by LC-DAD-MS-MS.”, J. Agric. Food Chem., 50 (20). 5691-5696. 2002.

[10] Carrillo-Lopez, A., Ramirez-Bustamante, F., Valdez-Torres, J., Rojas-Villegas, R., \& Yahia, E., "Ripening and quality changes in 
mango fruit as a ected by coating with an edible film”, Journal of Food Quality, 23 (5). 479-486. 2000.

[11] Castillo, S., Navarro, D., Zapata, P.J., Guillen, F., Valero, M., Serrano, D. and Martinez-Romero, "Antifungal efficacy of Aloe vera in vitro and its use as a postharvest treatment to maintain postharvest table grape quality”, Postharvest Biology and Technology, 57 (3). 183-188. 2010.

[12] Cock, I.E., "Antimicrobial activity of Aloe barbadensis Miller leaf gel components". The Internet Journal of Microbiology, 4 (2). 2008.

[13] Dureja, H., Kaushik, D., Kumar, N. and Sardana, S., “Aloe Vera. The Indian Pharmacist IV”, 38. 9-13. 2005.

[14] Ergun, M. and Satici, F., "Use of Aloe Vera gel as Biopreservative for Granny Smith and Red Chief Apples”, The Journal of Animal and Plant Sciences, 22 (2). 363-368. 2012.

[15] Gage, D., Aloe vera: Nature's Soothing Healer, Inner Traditions/Bear, USA, 1996, 3.

[16] Habeeb, F., Shakir, E., Bradbury, F., Cameron, P., Taravati, M.R., Drummond, A.J., Gray, A.I., Ferro, V.A., "Screening methods used to determine the anti-microbial properties of Aloe vera inner gel methods,” Methods, 42 (4). 315-320. 2007.

[17] Hamman, J.H., "Composition and application of aloe vera leaf gel”, Molecules, 13. 1599-1616. 2008.

[18] Krochta, J. M. and Mulder-Johnston, C. D., "Edible and biodegradable polymer films: Challenges and Opportunities", Food Technology, 51 (2). 61-74.1997.

[19] Lin, D. and Zhao, Y. 2007, "Innovations in the development and application of edible coatings for fresh and minimally processed fruits and vegetables”, Comprehensive Reviews in Food Science and Food Safety-CRFSFS, 6 (3). 60-75. 2007.

[20] Lone, M.A., Dinisha, M., Pooja, M., Aarti, D., Safena, R.C, “Antiinflammatory and antimicrobial activity of anthraquinone isolated from Aloe vera (Liliaceae)”, Asian Journal of Chemistry, 21 (3). 1807-1811. 2009

[21] Luo, Y.B. and Cai, T.Y., Storage and Process of Horticulture Product, China Agricultural University Publishing Company, Beijing, 2001, 3-25.

[22] Martinez-Romero, D, Alburquerque, N., Valverde, J., Guillen, F., Castillo, S., Valero, D. \& Serrano, M., "Postharvest sweet cherry quality and safety maintenance by Aloe vera treatment: A new edible coating”, Postharvest Biology and Technology, 39 (1). 93 100.2006.

[23] Maughan, R. G., "Method to increase color fastness of stabilized aloe vera.”, US Patent 4,465,629. 1984.

[24] Mchugh, T. H. and Senesi, E., "Apple wraps: A novel method to improve the quality and extend the shelf life of fresh-cut apples", Journal of Food Science, 65 (3). 480-485. 2000.

[25] Morillon, V., Debeaufort, F., Blond, G., Capelle, M., \& Voilley, A., "Factors affecting the moisture permeability of lipid-based edible flms: A review", Critical Reviews in Food Science and Nutrition, 42 (1). 67-89. 2002.
[26] Ni, Y., Turner, D., Yates, K.M., Tizard, I., "Isolation and characterization of structural components of Aloe vera L. leaf pulp”, International Immunopharmacology, 4 (14). 1745-1755. 2004.

[27] Nidiry, E., Ganeshan, G., \& Lokesha, A., “Antifungal activity of some extractives and constituents of aloe vera,” Research Journal of Medicinal Plant, 5 (2). 196-200. 2011

[28] Nunan, K. J., Sims, I. M., Bacic, A., Robinson, S. P., Fincher, G. B., "Changes in cell wall composition during ripening of grape berries”, Plant Physiology, 118 (3). 783-792. 1998.

[29] Pranoto, Y., Rakshit, S.K., Salokhe, V.M., "Enhancing antimicrobial activity of incorporating chitosen films by garlic oil, potassima sorbate and nisin", Lebensmittel Wissenschaft and Technology, 38 (8). 859-865. 2005b.

[30] Pranoto, Y., Salokhe, V.M., Rakshit, S.K., "Physical and antibacterial properties of alginate-based edible film incorporated with garlic oil”, Food Research International, 38 (3). 262-272. 2005a.

[31] Rowe, T. D. and Parks, L. M., “A phytochemical study of Aloe vera leaf”, Journal of the American Pharmaceutical Association, 30(10). 262-266. 1941.

[32] Schmelzer, G.H., Medicinal Plants, PROTA, Backhuys Publishers, Wageningen, 2008, 82.

[33] Serrano, M, Valverde, J., Guillen, F, Castillo, S, Martinez-Romero, D, \& Valero, D., "Use of Aloe vera gel coating preserves the functional properties of table Grapes”, Journal of Agricultural and Food Chemistry, 54 (11).3882-3886.2006.

[34] Shelton, R.M., "Aloe vera: Its chemical and therapeutic properties”, International Journal of Dermatology, 30 (10). 679683.1991.

[35] Srinu, B., Vikram, K.B., Rao, L.V., Kalakumar, b., Rao, T.M. and Reddy, A.G., " Screening of antimicrobial activity of Withania somnifera and Aloe vera plant extracts against food borne pathogens”, Journal of Chemical and Pharmaceutical Research, 4 (11). 4800-4803. 2012.

[36] Sumnu, G, \& Bayindirli, L., "Effects of Semperfresh (Tm) and Johnfresh(Tm) Fruit Coatings on Poststorage Quality of Ankara Pears”, Journal of Food Processing and Preservation, 18 (3). 189199. 1994.

[37] Tripathi, P. \& Dubey, N., "Exploitation of natural products as an alternative strategy to control postharvest fungal rotting of fruit and vegetables”, Postharvest Biology and Technology, 32 (3). 235-245. 2004.

[38] Valverde, J., Valero, D., Martinez-Romero, D., Guillen, F., Castillo, S., \& Serrano, M., "Novel edible coating based on Aloe vera gel to maintain table grape quality and safety", Journal of Agricultural and Food Chemistry, 53 (20). 7807-7813. 2005.

[39] Vogler, B. K. and Ernst, E., “Aloe vera: a systematic review of its clinical effectiveness”, British Journal of General Practice,49 (447). 82-90. 1999.

[40] Zagory, D. \& Kader, A., "Modified Atmosphere Packaging of Fresh Produce”, Food Technology, 42 (9). 70-77. 1988. 